\title{
EFISENSI DISTRIBUSI PENDAPATAN DALAM EKONOMI ISLAM
}

\author{
Abdul Qodir \\ Prodi Perbankan Syariah, Fakultas Agama Islam, Universitas Nahdlatul Ulama \\ Indonesia (UNUSIA) \\ Email: qodir@unusia.ac.id
}

Article Information

http://journal.unusia. ac.id/index.php/moz

aic/

DOI:

10.47776/mozaic.v7i

1.174

Informasi Artikel

Naskah diterima: 18

Februari 2021

Naskah direvisi: 30

Maret April 2021

Naskah disetujui: 24

April 2021

Naskah dipublish:

27 April 2021

Keywords

Efficiency

Distribution, Islamic

Perception, Islamic

Economic

Kata Kunci Efisiensi

Distribusi Persepsi

Islam, Ekonomi

Islam
Abstact

The object of this study is focused on how the efficiency of distribution in Islamic and conventional economic systems, while the data used is in the form of scientific works and writings related to distribution, then the data analysis is a descriptive qualitative method. The theory used is related to distribution as Adiwarman A Karim's opinion, which states that justice in the distribution system does not have any parties being judged. The conclusion of the paper is that the efficiency of allocation and distribution of income based on the Islamic perspective can be said to be efficient if it has been fulfilled and there are no parties being judged.

Tujuan dari tulisan ini ingin mengetahui bagaimana pola distribusi produksi dalam islam dan konvensional. Sedangkan masalah yang dirumuskan adalah bagaimana efektifitas distribusi produksi tanpa harus merugik an salah satu pihak, sehingga distribusi akan sampai pada pasar yang menjadi tempat pertemuan antara pedagang dan konsumen. Objek dari kajian ini difokuskan pada bagaimana efisiensi distribusi dalam sistem ekonomi islam dan konvensional, adapun data yang digunakan berupa karya ilmiyah mau pun tulisan yang terkait dengan distribusi, kemudian analisa data tersebut metode deskriptif kualitatif. Teori yang digu nakan terkait distribusi sebagaimana pendapat Adiwarman A Karim yang mengatakan, bahwa keadilan dalam sistem distribusi tidak adanya pihak yang didhalimi.Kesimpulan dari tulisan yaitu efisiensi alokasi dan distribusi pendapatan berdasarkan perspketif Islam dapat dikatakan efisien apabila telah terpenuhi dan tidak adanya pihak yang didhalimi. 


\section{PENDAHULUAN}

Distribusi pendapatan sangatlah penting untuk diperhatikan dalam kehidu pan ekonomi masyarakat, sehingga suatu ekonomi dapat dialokasikan secara efisien oleh individu. ${ }^{1}$ Efisiensi alokasi dan pendistribusian pendapatan dalam system ekonomi kapitalis memberikan dampak ketidakadilan serta ketimpangan pendapatan pada masyarakat, sehingga dapat menimbulkan konflik dan menciptakan kemiskinan y ang permanen bagi masyarakat. Namun, dalam mencapai kesejahteraan masyarakat secara kasat mata memang seperti tidak adanya campur tangan pemerintah. ${ }^{2}$

Pertanyaan yang muncul kemudian adalah bagaimana suatu individu dapat mengalokasikan sumber daya secara efisien, ketika individu telah mencapai titik kepuasan maksimal yang dapat bermanfaat bagi diri sendiri dan juga orang lain. Islam telah mengatur norma-norma tentang efisiensi alokasi dan distribusi pendapatan. Norma-norma inilah yang membedakan dengan konsep konvensional. Dalam islam, konsep kepemilikan adalah suatu yang sah namun kepemilikan kekayaan oleh individu sebagian adalah milik orang lain, bahwa kemaslahatan bukan hanya dirasakan oleh sebagian individu saja, melainkan harus memberikan kemaslahatan bagi orang lain yang juga harus diutamakan, sehingga keselamatan dunia dan akhirat akan dapat dicapai. ${ }^{3}$ Artinya bahwa suatu individu dapat megalokasikan maupun mendistribusikan sumberdaya yang dimilki bukan hanya untuk dapat memenuhi kepentingan sendiri, namun harus juga memikirkan kepentignan orang lain.

Alokasi distribusi pendapatan yang efisien dan yang tidak keluar dari korid or syariah telah diatur dalam Islam. Karena ketidakseimbangan distribusi kek ayaan akan mengakibatkan konflik dalam bermasyarakat, bahkan kemiskinan yang berkepanjangan. Pada dasarnya kemiskinan sendiri dapat dapat diatasi dengan cara yang sistematis. ${ }^{4}$ Penerapan konsep moral dan juga kedisiplinan dalam islam sebagai faktor penting dalam membimbing setiap individu ke dalam sistem ekonomi. Hal ni bertujuan untuk mencegah terjadinya ketidakadilan ekonomi dan ketimpangan so sial

\footnotetext{
${ }^{1}$ Yuke Rahmawati, "Refleksi Sistem Distribusi Syariah padaLembaga Zakat" Al-Iqtishad: Vol. III, No. 1, Januari (2011), 94-111

${ }^{2}$ Risna Nurhaida Hafn, "Efisiensi Aloka si Dan Distribusi Pendapatan Da lam Ekonomi Islam” Vol. I. No. 2/ Juli (2019), 233-241

${ }^{3}$ Siti Mardiyah dan Mahmud Alfan Jamil, "Efisiensi Aloka si Berdasarkan Maqashid Sy ariah: Stu di Ka sus Terhadap Pola DIstribusi LAZ" I-Finance e Vol. 2. No. 2 Desember (2016), 31-32

${ }^{4}$ https://www.komnasham.go.id/index.php/news/2015/9/11/197/ketimpan gan-ekonomi-menyebabkanpotensi-konflik.html dia kses 19 April 2021
} 
yang menjadi penyebab terpecahnya kerukunan umat islam itu sendiri. Islam telah mengatur secara jelas dan terperinci mengenai masalah tersebut.

\section{METODE PENELITIAN}

Jenis penelitian ini berupa pene;itian kualitatif, sedangkan analisis yang digunakan dalam penelitian ini berupa deskriptif kualitatif dengan cara menganalisa data yang didapatkan dari hasil observasi berbagai sumber buku maupun jurnal yang berkesesuaian dengan tema dan kemudian dianalisa dengan teori yang digunakan dalam sistem distribusi maupun efisiensi alokasi

\section{KAJIAN TEORI}

Distribusi dalam konsep ekonomi konvensioal dimaknai sebagai sebagai perpindahan barang dari perusahaan menuju pasar dengan tujuan ahir berada di tangan konsumen. ${ }^{5}$ Artinya bahwa bergeraknya barang yang diproduksi harus sampai ke tangan konsumen sebagai tujuan ahir dari peredaran barang yang dapat meningkatkan produksi barang tersebut. Distribusi secara sederhana dapat berupa saluran atau perpindahan barang menuju pasar. Kegiatan distribusi adalah segala bentuk perpindahan secara fisik barang dari jalur atau tempat produksi menuju konsumen ahir dengan menggunakan jangka waktu tertentu, proses inilah dinamakan distribusi. $^{6}$

\section{SISTEM DISTRIBUSI PENDAPATAN}

Nilai dasar yang membentuk sistem kapitalis berupa paham materialismhedonism dan sekuler, paham ini cenderung mengarahkan bahwa kehidupan materi duniawi adalah segalanya. Paham materialisme ini lebih cenderung untuk membawa kehidupan manusia berrientasi pada kesenangan, kenikmatan secara fisik semata, dan juga kekayaan duniawi. Beda halnya dengan pemahaman sekularisme yang memisahkan antara dimensi agama dan ilmu pengetahuan, bahkan cenderung abai terhadap norma dan moral. Sehingga konsep ini justru akan membawa manusia sebagai pusat dalam hal kehidupan (antrophosentris), manusia lebih berhak menentukan jalan hidupnya sendiri. ${ }^{7}$

\footnotetext{
${ }^{5}$ Kunarjo, Glosarium Ekonomi, Kuangan dan Pembangunan, (Jakarta: Universitas In done sia Perss, 2003), Cet. Ke-1, h. 81

${ }^{6}$ Tjiptono, Fa ndy. Strategi Pemasaran.(Yogyakarta: Penerbit Andi, 2008) 204

${ }^{7}$ Hendrie MB Anto, Pengantar Ekonomika Mikro Islami. (Yogyakarta: Ekonisia, 2003), 358-359
} 
Dominasi sistem ekonomi pasar termasuk indonesia masih mengandung kelemahan, yaitu terjadinya tidak merata dan ketimpangan sosial yang mengakibatkan ketidak selarasan maksimalisasi profit maupun krisis moral. Adanya kecenderungan sistem ekonomi pasar dapat menyebabkan tujuan dari ekonomi islam sulit untuk dicapai. $^{8}$

Distribusi merupakan bagaimana cara penyebaran suatu produk agar sampai di tangan konsumen, melalui cakupan suatu wilayah yang dapat dijangkau produk tersebut oleh konsumen. Sedangkan dalam distribusi juga terdapat perbedaan bagaimana sebuah produk dapat tersampaikan kepada konsumen, hal ini biasanya tergantung bagaimana tempat tinggal konsumen akan dapat terjangkau oleh suatu produk tersebut. ${ }^{9}$

Terlepas bagaimana caranya pendistribusian barang atau jasa sampai hingga sampai di tangan konsumen. Distribusi merupakan kegiatan penyaluran barang y ang merupakan sebuah jembatan antara produsen dan dan konsumen, sehingga barang tersebut menjadi berguna dan bermanfaat bagi orang lain. Proses pembagian merupakan suatu distribusi pada faktor yang ikut andil dalam menentukan pendapatan. Dalam sistem ekonomi Islam hal ini didasarkan pada dua nilai, yaitu nilai kebebasan dan keadilan. Hal ini merupakan prinsip moral yang tercermin dalam ajaran islam tentang kepemilikan individu, umum, dan warisan. ${ }^{10}$

Ilmu ekonomi Islam merupakan ilmu dengan dasar keagamaan secara integral yang mempelajari usaha manusia untuk mengalokasikan serta mengelola sumber daya agar mencapai falah, adapun nilai yang dibangun berdasarkan pada prinsip-prinsip maupun nilai-nilai yang tercantum dalam al-Qur'an dan as-Sunnah. Amanah yang diberikan oleh Allah kepada umat manusia sebagai pengolah sumber kekay aan serta diberi kewenangan untuk memiliki kekayaan tersebut. ${ }^{11}$

Dapat disimpulkan, bahwa antara ekonomi islam dan agama terdapat hubungan yang erat satu sama lain sebagai dasar untuk menjalankan roda

\footnotetext{
${ }^{8}$ Heri Sudarsono, Konsep Ekonomi Islam, Suatu Pengantar, (Yogyakarta: Ekonisia, 2002), 84-86

${ }^{9}$ MuhdiB. Hi. Ibrahim, "Analisis Pengaruh Produk Dan Distribusi Terhadap Kepu tusan Pe mbelia n Motor Honda Pada CV. Fajar Baru Ja yapura" Future Jurnal Manajemen dan Akuntansi, 1 (2), (2014) $198-213$

${ }^{10}$ Zuraidah "Penerapan Konsep Moral Dan Etika Dalam Distribusi Pendapatan Persp ek tif Ek onomi Islam"Hukum Islam, Vol. XIII, No. 1, Nov (2013), 137-153

${ }^{11}$ Putri Nuraini, Rika Septianingsih, dan Mod. Ario Wahdi Else, "Studi Ayat-ayat Ekonomi Ten tang Al-milk serta Klasifikasi Kepemilikan" Jurnal ISLAMIKA, Vol. 3, No. 2 (2020): 44-45
} 
perekonomian dalam masyarakat luas. Setidaknya ini adalah salah satu ciri sebagai pembeda antara ekonomi islam dan konvensional, bahwa di setiap kegiatan perekonomian agar tercapai sebuah kondisi antara output dan input yang seimbang dalam kesejahteraan sesuai dengan kapasitasnya masing-masing di masyarakat.

Pola efisiensi alokasi distribusi pendapatan dalam ekonomi islam dan konvensional tentu tidak asing lagi terdengar, namun perbedaan efisiensi alokasi ekonomi konvensional dikenal sebagai efficient allocation of goods yaitu barang dapat dikatakan efisien jika tidak ada individu y ang dapat meningkatkan utility -n y a, tan pa mengurangi utility yang lain. Sehingga, keadaan yang dianggap efisien apabila keadaan lainnya masih dapat memiliki peluang untuk meningkatkan kegunaan seseorang tanpa mengurangi utility orang lain. ${ }^{12}$

Adil atau tidaknya sebuah alokasi dalam teori ekonomi konvensional tidak dapat dijelaskan. Dengan demikian, apabila adil diartikan sebagai "sama rasa sama rata". Hal ini sangat berbeda dengan makna ekonomi Islam, dimana y ang dimak sud dengan adil adalah tidak semestinya sama rasa sama rata, melainkan yang paling penting adalah tidak mendzalimi dan tidak didzalimi. ${ }^{13}$ Begitupun dengan distribusi pendapatan, dalam system ekonomi Islam sangat melindungi umatnya. Sehingga, dalam ekonomi Islam terdapat hak milik pribadi yang didalamnya terdapat hak milik orang lain. Karena, pada dasarnya hakikat harta merupakan milik Allah. ${ }^{14}$

Distribusi dalam sistem ekonomi Islam pada hakikatnya mempertemukan kepentingan konsumen dan produsen dengan tujuan kemaslahatan umat. Pelaku distribusi kini telah menjadi pelaku ekonomi dominan di samping konsumen dan produsen. Distribusi dalam pandangan Islam didasarkan pada dua nilai manusiawi yang sangat mendasar dan penting sebagaimana Rozalinda yang mengutip Yusuf Qordowi, bahwa distribusi dalam islam berdasar pada nilai kebebasan dan nilai keadilan. ${ }^{15}$

\footnotetext{
${ }^{12}$ AM. M. Hafidz MS, "Distribusi Faktor Produksi:Pemerataan Kesejahtera an Ekonomi Melalui Distribusi Faktor Produksi” Jurnal Hukum Islam, vol, 8. No. 1, Juni (2010), 89-109

${ }^{13}$ Risna Nurhaida Hafn, "Efisiensi Alokasi Da n Distribusi Pendapatan Da lam EkonomiIslam” Vol. I. No. 2/ Juli (2019), 240-241

${ }^{14}$ Niza ruddin, "Konsep Kepemilikan Harta PerspektifEkonomiSyari' ah." Adzkiya: Jurnal Hukum dan Ekonomi Syariah 6, no. 2 (2019),10-30

${ }^{15}$ Rozalinda, Ekonomi Islam Teori Dan Aplikasinya Pada Aktifitas Ekonomi, (Jakarta: PT. Raja Grafindo Persada, 2014), 115
} 
Terdapat dua sistem ditribusi dalam islam yakni: distribusi secara komersial dan mengikuti mekanisme pasar serta sistem distribusi yang bertumpu pada aspek keadilan sosial masyarakat. Distribusi yang bertumpu pada aspek keadilan sosial masyarakat dilakukan dengan cara adanya aliran barang maupun jasa yang diberikan oleh salah satu pihak kepada pihak lain, tanpa meminta timbal balik dari pihak tersebut. ${ }^{16} \mathrm{Hal}$ ini setidaknya sejalan dengan ayat qur'an yang artinya:" Artinya: "Hai orang-orang yang beriman, janganlah kamu saling memakan harta sesamamu dengan jalan yang batil, kecuali dengan jalan perniagaan yang berlaku dengan suka samasuka di antara kamu.” (Qs. al-Nisa' [4]: 29).

Bukan hanya dilakukan oleh satu dua orang saja, akan tetapi pada distribusi ini dapat dilakukan oleh negara. Misalnya, negara memberikan lahan tanah k osong untuk warganya yang tidak memiliki tempat tinggal, dan lain sebagainya. Hal ini dalam istilah fiqh dikenal sebagai iq tha'. Maka dari itu, dengan adanya 2 (dua) mekanisme inilah ekonomi Islam menjamin akan terpenuhinya kulliyatul akhamsah. ${ }^{17}$

Musthafa Syukur mengutip dari Yusuf Qardhawi menjelaskan, bahwa distribusi dalam ekonomi kapitalis terfokus pada pasca produksi, yaitu pada konsekuensi proses produksi bagi setiap proyek dalam bentuk uang ataupun nilai, lalu hasil tersebut didistribusikan pada komponen-komponen produksi yang tergabung dalam proses produksinya. ${ }^{18}$ Ada 4 bagian yang berkaitan dengan distribusi hasil produksi, yaitu:

1. Upah atau gaji untuk para pekerja;

2. Bunga sebagai imbalan modal yang dipinjam oleh pengelola proyek;

3. Sewa tanah yang digunakan untuk melaksanakan proyek itu dan

4. Laba/profit bagi para manajer yang mengelola dan mengurusi pelaksanaan proyek, dan juga sebagai penanggung jawabnya.

Namun, untuk ke empat bagian yang berkaitan dengan distribusi di atas tidaklah selalu berjalan dengan normal. Untuk upah atau gaji yang diberikan kepada para pekerja biasanya tidak sesuai dengan apa yang mereka kerjakan atau tidak

\footnotetext{
${ }^{16}$ Marabona Munthe, Konsep Distribusidalam Islam” Jurnal Syariah Vol. 2, No. 1, April (2014), 78 81

${ }^{17}$ Muja hidin, "Konsep Iqtha' Pemberian Tanah Kepada Masyarakat DalamPemikira n Ekonomi AlMa wardi(Studi Kitab Al-AhkamAl-Sulta niyyah)," Vol.2, No. 1, Ma ret2017), 14

${ }^{18}$ Musthafa Syukur, "Distribusi Perspektif Etika Ekonomi Islam" Profit: Jurnal Kajian Ek onomi d a n Perbankan 2 (2) 2018. P: 33-51
} 
sebanding dengan pekerjaan yang mereka pikul. ${ }^{19}$ Keuntungan sebagai imbalan modal yang dipinjam oleh pengelola proyek merupakan bunga (interest on capital). Sedangkan di dalam Islam sudah jelas bahwa bunga atau riba itu dilarang, sedangkan di dalam riba terdapat beberapa tingkatannya masing-masing dan tahapan mengenai riba itu sendiri. ${ }^{20}$

Untuk laba bagi para manajer yang mengelola, dan mengurusi pelaksanaan proyek, dan sebagai penanggung jawabnya termasuk juga dalam riba. Apabila seorang manajer memperoleh tambahan laba atau keuntungan dari hasil mengelola dan mengurusi pelaksanaan proyek maka hal itu di golongkan dalam kategori riba karena untuk manajer sudah ada gaji pokok yang diperolehnya. Hal ini yang melatar belakangi Islam menolak dua nomor dari yang disebutkan diatas yaitu nomor dua dan empat.

Berikut ini beberapa konsep Islam yang terdapat dalam Al-Qur'an yang berkaitan dengan distribusi pendapatan:

1. Kedudukan manusia yang berbeda antara satu dengan yang lain merupakan kehendak Allah.

Didalam Al-Qur'an telah di jelaskan dalam surat al-An'am (6) ayat 165 yang artinya: "Dan Dialah yang menjadikan kamupenguasa-penguasa di bumi dan Dia meninggikan sebahagian kamu atas sebahagian (yang lain) beberapa derajat, untuk mengujimu tentang apa yang diberikan-Nya kepadamu. Sesungguhnya Tuhanmu amat cepat siksaan-Nya, dan sesungguhnya Dia Maha Pengampun lagi Maha Penyayang”.(Qs. Al-an’am: 165)121

Allah telah menciptakan makhluknya sebagai pemimpin di muka bumi dan Allah yang telah menjadikan derajat manusia berbeda-beda, ada y ang kay a dan ada pula yang miskin supaya hal itu dapat dijadikan sebagai suatu ujian, ${ }^{21}$ lalu Allah memberikan balasan atas amal yang dilakukan di dunia. Sehingga manusia tidak dapat menentukan dirinya berada dalam posisi yang lebih tinggi atau lebih rendah, karena yang menentukan hanyalah Allah. Pemilikan harta pada hanya beberapa orang dalam

\footnotetext{
19 Yusuf Al-Qaradhawi, Dawr al-Qiyam wa l-Akhlaqi fi al-Iqtishad al- Islam, Terj.Didin Hafidhuddin.Peran Nilaidan Moral dalam Perkonomian Islam,(Jakarta: Robbani Press, 2004), .347

${ }^{20}$ Ade Dedi Rohayana "Riba dalam Tinjauan Al-Quran." Religia (2015): 72-86.

${ }^{21} \mathrm{https}$ ://ahmadiyah.id/islam/allah-swt/mengapa-allah-menciptakan-perbedaan-derajat-manusia diakses pada $20 / 04 / 2020$
} 
suatu masyarakat akan menimbulkan ketidak seimbangan hidup dan preseden/kejadian buruk bagi kehidupan. ${ }^{22}$ Hal tersebut sudah dijelaskan dalam AlQur'an QS. Huud: 116

"Maka mengapa tidak ada dari umat-umat yang sebelum kamu orang-orang yang mempunyai keutamaan yang melarang daripada (mengerjakan) kerusakan di muka bumi, kecuali sebahagian kecil di antara orang-orang yang telah Kami selamatkan di antara mereka, dan orang-orang yang zalim hanya mementingkan kenikmatan yang mewah yang ada pada mereka, dan mereka adalah orang -orang yang berdosa."

Dalam ayat diatas disebutkan "dan orang-orang yang zalim hanya mementingkan kenikmatan yang mewah yang ada pada mereka, dan mereka adalah orang-orang yang berdosa." (Q.S. Hud, 116) Apabila dalam suatu masyarakat terdapat kejadian yang demikian, orang yang mampu merendahkan orang yang kurang mampu, maka akan mengakibatkan orang yang tidak mampu tersebut menjadi rendah diri dan akan terjadi sifat yang tidak syukur nikmat. Sehingga dalam hal ini diperlukan adanya distribusi.

2. Pemerintah dan masyarakat mempunyai peran penting untuk mendistribusikan kekayaan kepada masyarakat. ${ }^{23}$

Hal tersebut juga telah dijelaskan dalam QS. Adz Dzariyat ayat 19 yang berbunyi: "Dan pada harta-harta mereka ada hak untuk orang miskin yang me minta dan orang miskin yang tidak mendapat bahagian. "

Pemerintah tentunya juga memiliki peranan penting dalam hal pendistribusian kekayaan kepada masyarakat. Karena seperti yang telah diterangk an oleh ayat di atas bahwa di dalam harta-harta mereka ada hak orang miskin yang meminta dan orang miskin yang tidak mendapat bahagian atau orang miskin yang malu untuk memintaminta.

\footnotetext{
${ }^{22}$ Itang \& Adib Daenuri, "Sistem Ekonomi Kapitalis, Sosia lis Dan Islam” TAZKIYA Jurnal Keislaman, Kemasyarakatan \& Kebudayaan, Vol. 18 No. 1 (Januari-Juni) (2017), 67-90

${ }^{23}$ Eli Suryani, "Distribusi pendapatan Dan Pemenuhan Kebutuhan Dalam Ekonomi Islam” AlHurriyah, Vol. 11, No. 2, Juli-Desember(2010), 61-84
} 
3. Islam menganjurkan untuk membagikan harta lewat zakat, sedekah, infaq dan lainnya guna menjaga keharmonisan dalam kehidupan sosial.

Terdapat dalam QS. Al-Hasyr ayat 7 yang artinya: “Apa saja harta rampasan (fai-i) yang diberikan Allah kepada Rasul-Nya yang berasal dari penduduk kota-kota maka adalah untuk Allah, Rasul, kerabat Rasul, anak-anak yatim, orang-orang miskin dan orang-orang yang dalam perjalanan, supaya harta itu jangan hanya be redar di antara orang-orang kaya saja di antara kamu. Apa yang diberikan Rasul kepadamu maka terimalah dia. Dan apa yang dilarangnya ba gimu maka tinggalkanlah; dan bertakwalah kepada Allah. Sesungguhnya Allah sangat keras hukuman-Nya."

Allah menganjurkan bagi orang-orang yang mampu atau orang kaya untuk memberikan sebagian hartanya kepada orang kurang mampu melalui zakat, infaq dan shadaqah agar terjadi keseimbangan antara keduanya sehingga harta tidak beredar di kalangan orang kaya saja. ${ }^{24}$

\section{EFISIENSI ALOKASI}

Istilah efficient allocation of goods lebih dikenal dalam sistem ekonomi konvensional. Artinya bahwa barang dapat dikataka efisien jika terdapat individu yang utilitynya dapat meningkat tanpa harus mengurangi utility orang lain. Dapat dianggap efisien kalau keadaan yang lainnya terdapat peluang untuk meningkatkan bergunanya seseorang tanpa harus mengurangi orang yang lainnya. ${ }^{25}$

Tidak adanya kejelsan dalam sistem ekonomi konvensional mengenai keadilan dalam alokasi. Jika adil diartikan sebagai "sama rasa sama rata", Akan tetapi, beda halnya dalam konsep ekonomi Islam, adil yang dimaksud tidaklah sama rata dan sama rasa, justru yang terpenting yaitu tidak adanya yang mendhalimi dan yang didhalimi. imam Ali r.a diriwayatkan pernah mengatakan: "janganlah kesejahteraan seseorang diantara kamu meningkat namun pada saat yang sama kesejahteraan yang lain menurun". Jika sumberdaya habis teralokasikan, maka itulah yang dinamakan efisensi alokasi, namun dalam sistem ekonomi konvensional tidak menjelaskan bagaimana alokasi yang adil atau tidak adil tersebut. ${ }^{26}$

\footnotetext{
${ }^{24}$ Taufik Hidayat, "Konsep Pendistribusian Kekayaan Menurut Al-Qur'an” Al Falah: Journal of Islamic Economics, Vol. 2, No. 1, (2017), 14-36

${ }^{25}$ Siti Mardiyah, "Efisiensi Alokasi Da lam Pandangan Adiwa rman A. Ka rim” Islamic Banking Vol. 2. Nomor 1 Edisi, Agustus (2016), 20

${ }^{26} \mathrm{Ma}$ 'ruf Abdullah, "Perbedaan Pa radigma Ekonomi Konvensional Dan Ekonomi Islam Dalam Teori dan Realita" AT - TARADHI JurnalStudiEkonomi, Volume3, Nom or 1, Juni(2012), 40
} 


\section{EFISIENSI DAN KEADILAN}

Efisiensi adalah perbandingan antara input dan output, di mana input digunakan setepat dan sebaik mungkin untuk memperoleh output yang terbaik. ${ }^{27}$ Efisiensi alokasi menjelaskan bahwa bila semua sumber daya yang ada habis teralokasi, maka akan mencapai alokasi yang efisien, tetapi tidak dapat dikatakan bahwa alokasi tersebut adil. Karena tiap unit dalam pertukaran ekonomi di pasar keunggulannya modal awal antara satu dengan yang lainya berbeda. Misalnya, endowment individu 1 lebih banyak pada barang 1 sedangkan individu 2 memiliki lebih banyak barang 2 . Kondisi tersebut akan memacu masingmasing individu untuk membuat dirinya better-off dengan melakukan perdagangan barang 1 dan 2 . Pertukaran tersebut akan berakhir pada kondisi alokasi yang efisien, dimana tidak dapat lagi suatu individu menambah utility-nya terhadap suatu barang (better-off) tanpa membuat utility individu lainnya dirugikan (worse-off). ${ }^{28}$

Konsep ekonomi Islam juga mendorong pada upaya membesarkan endowment (meningkatkan production possibility frontier) atau dalam konteks ini membesarkan Edgeworth Box. Berkutat pada distribusi yang berkeadilan saja berarti suatu zero sum game. Misalnya utility jono naik 5, utility kirun turun 5, kenaikan total utility nihil. ${ }^{29}$ Hal ini dikarenakan dalam konsep ekonomi Islam,

1. Adanya konsep adil dalam Islam adalah "tidak menzalimi dan tidak dizalimi. Bisa dengan endowment" sama rata atau endowment tidak sama rata.

2. adanya Ziswaf (zakat, infak dan sadaqoh) karena nilainya sejalan dengan maksimalisasi Production Possiblity Frontier. Sedagkan Untuk dapat memaksimalkan utility dengan memberikan zakat, infaq dan sodaqoh jika, telah mencapai Production Possiblity Frontier. Artinya seseorang da[at mengeluarkan zakat, infaq dan sodaqoh jika telah mencapai kadar nisab dan haulnya. ${ }^{30}$ Jika ingin membesarkan utility orang lain, maka ia harus membesarkan utility pribadi dengan mengeluarkan sodaqoh dengan memaksimalkan input.

\footnotetext{
${ }^{27}$ http://adydaryanto.staff.gunadarma.ac.id/Downloads/files/59817/2.+PERAN+PEMERINTAH+DAL AM+BIDANG+EKONOMI.pdf . diakses pada 20 a pril 2021

${ }^{28}$ Adiwarman A. Karim, Ekonomi Mikro Islam, edisi kedua, (IIIT Indonesia, Jakarta, 2003)305

${ }^{29}$ Adiwarman A. Karim, 319

${ }^{30}$ Zakat mal memang ha rus menunggu jangka waktu saatu tahun, hal iniberbe da dengan in $\mathrm{faq}$ dan shodaqoh yang tidak harus menunggu haul, sebab infaq dan shodaqoh dapat dilakukan kapan saja baik da lam kondisiberpunyamaupun tidak berpunya
} 
Para ekonom konvensional berbeda pendapat tentang distribusi yang adil :

1. Konsep Egalitarian: Barang yang diterima pada setiap orang dalam kelompok masyarakat jumlahnya sama.

2. Konsep Rawlsian: maksimalkan utility orang paling miskin (The last well off person).

3. Konsep Utilitarian: maksimalkan total utility dari setiap orang dalam kelompok masyarakat

4. Konsep Market Oriented: hasil pertukaran melalui mekanisme pasar adalah yang paling adil

Dalam konsep ekonomi islam, adil adalah "tidak menzalimi dan tidak dizalimi". Bisa jadi "sama rasa sama rata" tidak adil dalam pandangan islam karena tidak memberikan insentif bagi orang yang telah melakukan kerja keras. Tidak adil dalam pandangan Islam karena orang yang endowmentnya tinggi mempunyai posisi tawar yang lebih kuat dari pada yang endowment nya kecil sehingga yang kuat dapat mendzalimi yang lemah. ${ }^{31}$ Lebih dari sekedar efisiensi dan keadilan, konsep ekonomi Islam juga mendorong pada upaya membesarkan endowment (meningkatkan production possibility frontier) atau dalam konteks ini membesarkan Edgeworth Box. Oleh karena itu, konsep Islam adalah mendorong terjadinya positive sum game. Misalnya utility Firman naik 5, utility si A naik 5, kenaikan total utility 10. Jadi bukan hanya mempermasalahkan bagaiamana "roti" akan akan dibagi secara adil namun bagaimana "roti" yang akan dibagi bertambah besar. ${ }^{32}$

\section{DAMPAK DISTRIBUSI PENDAPATAN DALAM ISLAM}

Distribusi pendapatan merupakan bagian yang penting dalam membentuk kesejahteran. Dampak dari distribusi pendapatan bukan saja pada aspek ekonomi tetapi juga aspek sosial dan politik. ${ }^{33}$ Dampak yang ditimbulkan dari distribusi pendapatan yang didasarkan atas konsep Islam adalah sebagai berikut:

\footnotetext{
${ }^{31}$ Eva Zulfa N, "Pengupahan Berkeadilan Menurut Hukum Islam Kajian Terhadap Ump DKI” INDOISLAMIKA, Vol. 5. No. 2 Juli - Desember(2015), 317-332

${ }^{32}$ AM. M. Hafidz MS, "Distribusi Faktor Produksi: Pemerataan Kesejahtera an Ekonomi mela lui Distribusi Faktor Produksi” Jurnal Hukum Islam Vol. 8, No.1, Juni 2010, (2016), 89-107

${ }^{33}$ Heri Sudarsono, Konsep Ekonomi Islam, Suatu Pengantar.(Yogyakarta:Ekonisia, 2002), 216
} 
1. Dalam konsep Islam perilaku distribusi pendapatan masyarakat merupakan bagian dan bentuk proses kesadaran masyarakat dalam mendekatkan diri kepada Allah.

2. Seorang muslim akan menghindari praktek distribusi yang menggunakan barang-barang yang merusak masyarakat.

3. Negara bertanggung jawab terhadap mekanisme distribusi dengan mengedepankan kepentingan umum daripada kepentingan kelompok, atau golongan apalagi perorangan dan juga memastikan agar jangan sampai sek tor publik jatuh ke tangan perorangan maupun kelompok. ${ }^{34}$

4. Negara memiliki tanggung jawab untuk menyediakan fasilitas publik, yang berhubungan dengan masalah optimalisasi distribusi pendapatan, seperti: sekolah, rumah sakit, lapangan kerja, perumahan, jalan, jembatan dan sebagainya, sektor publik ini mnjai tanggungjawab negara dalam rangka menjaga dan bentuk tanggunjawabnya terhadap rakyatnya.

Perolehan pendapatan harus dibarengi dengan kegiatan distribusi, sebab distribusi pendapatan itu sendiri dapat menjadi faktor penting dalam upaya memperbaiki kualitas perekonomian masyarakat, ${ }^{35}$ terlebih lagi jika pendapatan y ang didapatkan dan didistribusikan tersebut bersumber dari pekerjaan yang halal, maka distribusi pendapatan akan turut memperbaiki akhlak atau moral orang yang mendistribusikan dan yang mengonsumsinya. Tak hanya itu, distribusi pendapatan juga dapat mempererat hubungan sosial di antara masyarakat, sehingga konflik atau permasalahan politik akan sangat jarang terjadi, ini tentu saja karena tidak ada kebencian yang terpendam dalam hati, dan semua berawal dari rasa saling peduli.

\section{KESIMPULAN}

Efisiensi alokasi dan pendistribusian pendapatan dalam system ekonomi kapitalis memberikan dampak ketidakadilan serta ketimpangan pendapatan pada masyarakat, sehingga dapat menimbulkan konflik dan menciptakan kemiskinan berkepanjangan masyarakat. Tidak menutup kemungkinan kebobrokan terjadi dan

\footnotetext{
${ }^{34}$ Ummi Ka lsum, "Distribusi Pendapatan dan Kekayaan dalam Ekonomi Isla m"Li Fa lah, Jurnal St u di Ekonomi dan Bisnis Islam Vol. 3, No. 1, Juni (2018), 43

${ }^{35}$ Tesalonika Chrisdiantien Dondo, Noortje Marsella nie Benu, dan Elsje Pauline Mangin sela, "FaktorFaktor Yang Mempengaruhi Ketimpangan Distribusi Pendapatan Rumah Ta ngga Di Ka bu paten Minahasa” AGRIRUD - Vol.1.No.1, April (2019), 61
} 
bahkan kerusakan sistem ekonomi, maka memang seharusnya untuk merubah sistem ekonomi yang kapitalis dengan konsep ekonomi Islam ynag berlan dasrkan pada al Qur'an dan Hadits. Sistem distribusi dalam islam menginginkan maqosid syariah terpenuhi, artinya skala aspek prioritas antara Ad-daruriyyah, Al-hajjiyyah, dan Attahsiniyyah dapat dipenuhi sehingga kegiatan yang menimbulkan dhalim dan mendhalimi tidak ditemukan, dan kesejahteraan masyarakat tercapai, karena tidak adanya monopoli dalam distribusi.

\section{DAFTAR PUSTAKA}

Abdullah, Ma'ruf. "Perbedaan Paradigma Ekonomi Konvensional Dan Ekonomi Islam Dalam Teori dan Realita" AT - TARADHI Jurnal Studi Ekonomi, Volume 3, Nomor 1, Juni (2012)

Al-Qaradhawi, Yusuf, Dawr al-Qiyam wa l-Akhlaqi fi al-Iqtishad al- Islam, Terj.Didin Hafidhuddin.Peran Nilai dan Moral dalam Perkonomian Islam, (Jakarta: Robbani Press, 2004)

Anto, Hendrie MB, Pengantar Ekonomika Mikro Islami. (Yogyakarta: Ekonisia, 2003)

Daenuri, Adib dan Itang. "Sistem Ekonomi Kapitalis, Sosialis Dan Islam” TAZKIY A Jurnal Keislaman, Kemasyarakatan \& Kebudayaan, Vol. 18 No. 1 (JanuariJuni) (2017)

Dondo, Tesalonika Chrisdiantien, Noortje Marsellanie Benu, dan Elsje Pauline Manginsela, "Faktor-Faktor Yang Mempengaruhi Ketimpangan Distribusi Pendapatan Rumah Tangga Di Kabupaten Minahasa” AGRIRUD - Vol.1. No.1, April (2019)

Hafidz MS, AM. M. "Distribusi Faktor Produksi:Pemerataan Kesejahteraan Ekonomi Melalui Distribusi Faktor Produksi” Jurnal Hukum Islam, vol, 8. No. 1, Juni (2010)

Hidayat, Taufik. "Konsep Pendistribusian Kekayaan Menurut Al-Qur'an” Al Falah: Journal of Islamic Economics, Vol. 2, No. 1, (2017)

Kalsum, Ummi, "Distribusi Pendapatan dan Kekayaan dalam Ekonomi Islam” Li Falah, Jurnal Studi Ekonomi dan Bisnis Islam Vol. 3, No. 1, Juni (2018) 
Karim, Adiwarman A, Ekonomi Mikro Islam, edisi kedua, (IIIT Indonesia, Jakarta, 2003)

Kunarjo, Glosarium Ekonomi, Kuangan dan Pembangunan, (Jakarta: Universitas Indonesia Perss, 2003)

Marabona Munthe, Konsep Distribusi dalam Islam” Jurnal Syariah Vol. 2, No. 1, April (2014)

Mardiyah, Siti dan Mahmud Alfan Jamil, "Efisiensi Alokasi Berdasarkan Maqashid Syariah: Studi Kasus Terhadap Pola DIstribusi LAZ" I-Finance e Vol. 2. No. 2 Desember (2016)

Muhdi B. Hi. Ibrahim, “Analisis Pengaruh Produk Dan Distribusi Terhadap Keputusan Pembelian Motor Honda Pada CV. Fajar Baru Jayapura” Future Jurnal Manajemen dan Akuntansi, 1(2), (2014)

Mujahidin, “Konsep Iqtha' Pemberian Tanah Kepada Masyarakat Dalam Pemikiran Ekonomi Al-Mawardi (Studi Kitab Al-Ahkam Al-Sultaniyyah),” Vol.2, No. 1, Maret 2017)

N, Eva Zulfa, "Pengupahan Berkeadilan Menurut Hukum Islam Kajian Terhadap Ump DKI” INDO-ISLAMIKA, Vol. 5. No. 2 Juli - Desember (2015)

Nizaruddin, "Konsep Kepemilikan Harta Perspektif Ekonomi Syari’ah." Adzkiya: Jurnal Hukum dan Ekonomi Syariah 6, no. 2 (2019),10-30

Nurhaida Hafn, Risna. "Efisiensi Alokasi Dan Distribusi Pendapatan Dalam Ekonomi Islam" Vol. I. No. 2/ Juli (2019)

Rahmawati, Yuke. "Refleksi Sistem Distribusi Syariah pada Lembaga Zakat" AlIqtishad: Vol. III, No. 1, Januari (2011)

Rozalinda, Ekonomi Islam Teori Dan Aplikasinya Pada Aktifitas Ekonomi, (Jakarta: PT. Raja Grafindo Persada, 2014)

Sudarsono, Heri. Konsep Ekonomi Islam, Suatu Pengantar, (Yogyakarta: Ekonisia, 2002)

Syukur, Musthafa, "Distribusi Perspektif Etika Ekonomi Islam" Profit: Jurnal Kajian Ekonomi dan Perbankan 2 vol.2. (2018)

Zuraidah. "Penerapan Konsep Moral Dan Etika Dalam Distribusi Pendapatan Perspektif Ekonomi Islam” Hukum Islam, Vol. XIII, No. 1, Nov (2013) 